\title{
NON-CALLIPHORIDAE-NECROPHAGOUS-DIPTERA SUCCESSION ON PIG CARCASSES IN MANADO, INDONESIA
}

\author{
Sunny Wangko ${ }^{1}$ \\ Dantje T. Sembel ${ }^{1}$ \\ Oddi R. Pinontoan ${ }^{1}$ \\ Jimmy Posangi ${ }^{1}$ \\ Hans Huijbregts ${ }^{2}$
}

\author{
${ }^{1}$ University of Sam Ratulangi Manado, Indonesia \\ ${ }^{2}$ Nederlands Centrum voor Biodiversiteit Naturalis Leiden, Holland \\ Email: sunnywangko@yahoo.com
}

\begin{abstract}
Abstrak. Penelitian mengenai suksesi Diptera nekrofagus non-Calliphoridae dilakukan di Manado, Indonesia pada tahun 2012. Tiga ekor bangkai babi domestik (berat badan 21-23 kg) dimatikan dengan tiga cara yang berbeda (dosis letal potasium sianida per oral, pukulan benda tumpul pada area osipital, dan tikaman benda tajam). Penelitian dilakukan selama 15 hari. Suhu udara ambien dan kelembaban, serta data suhu dari Badan Meteorologi Klimatologi dan Geofisika (BMKG) Stasiun Klimatologi Kayuwatu. Babi yang dimatikan dengan potasium sianida memperlihatkan perlangsungan dekomposisi yang lebih panjang (10 hari) dibandingkan dengan lainnya (delapan hari). Simpulan: Terdapat empat famili dan dua spesies Diptera nekrofagus non-Calliphoridae yang mengunjungi bangkai hewan coba: Sarcophagidae, Piophilidae, Ophyra, Phoridae, Musca domestica, dan Hermetia illucens. Sarcophagidae dan Ophyra telah ditemukan sejak hari ke-1. Dari keenam jenis serangga nonCalliphoridae yang berkunjung, hanya empat jenis yang berkolonisasi pada bangkai hewan coba, yaitu: Ophyra, Phoridae, Musca domestica, and Hermetia illucens.
\end{abstract}

Kata kunci: nekrofagus non-Calliphoridae, babi domestik, suksesi, kolonisasi

\begin{abstract}
A study was conducted on Non-Calliphoridae-Necrophagous-Diptera succession on pig carcasses in Manado, Indonesia, in the year 2012. Three domestic pig carcasses (weighing $21-23 \mathrm{~kg}$ ) were killed by using three different manners (a lethal oral dose of potassium cyanide, a blow with a blunt material, and a stabbing with a sharp material). This study was conducted for 15 days. Ambient air temperatures and humidity, and temperature data of the Climatology Station, Kayuwatu were recorded. The pig killed with potassium cyanide showed a longer decomposition duration (10 days) than the others (eight days). Conclusion: there were four families and two species of Non-Calliphoridae-Necrophagous Diptera visited the carcasses: Sarcophagidae, Piophilidae, Ophyra, Phoridae, Musca domestica, and Hermetia illucens. The first visitors (day 1) were Sarcophagidae and Ophyra. From the six visitors, there were only four that colonized on the carcasses: Ophyra, Phoridae, Musca domestica, and Hermetia illucens.
\end{abstract}

Key words: Non-Calliphoridae-Necrophagous-Diptera, domestic pigs, succession, colonization

Insects constitute the biggest group of organisms that has survived for more than 300 million years. $^{1-4}$ These fauna have a high capasity of adaptation to the environment and occupy nearly all habitats in this world, ${ }^{3,5,6}$ including crime scenes. The usage of insects in forensic fields and medicolegal investigations belongs to Forensic Entomology. ${ }^{1,3,7,8}$

Insects (adult and immature) have 
been used in e.g. the estimation of post mortem interval (PMI), investigation of causes and manners of deaths, ${ }^{8}$ and finding out whether a dead body or its remains have been removed or not. ${ }^{8,9}$ In Indonesia, the insect identification technology, especially for the immature forms, has not beenwell developed. Morover, no database of forensic insects has been reported so far.

Insects visiting corpses or carcasses are commonly described based on their ecological roles: necrophagous, predatory and parasitoid, omnivorous, adentive, and accidental insects. ${ }^{10-12}$ These insects do not visit or leave the corpses abruptly, but in "waves", 2,13 called an insect succesion pattern, which differs from area to area, and country to country. ${ }^{11,12,14-16}$

Diptera and Coleoptera are the most important orders visiting corpses. Calliphoridae is the most successive family reported in many cases. Morover, Calliphoridae is the most published family as it is the first visitor to a dead body, but the other NonCalliphoridae-Diptera families or species are usually found on the corpse and play some important roles, too. ${ }^{8,17-19}$ Noncosmopolitan insects are very important in considering that a dead body or its remains have been removed. ${ }^{20}$ A continual database of forensic insects in every country is needed to obtain better results in medicolegal investigations. ${ }^{16}$

\section{MATERIAL AND METHODS}

\section{Carcasses}

Three domestic pigs, weighing 21-23 $\mathrm{kg}$, were killed by using three different manners (simulation of death manners in autopsied cases in Manado) in January 27, 2012. The first pig was given a lethal oral dose of potassium cyanide; the second one was strucked with a blunt instrument; and the third one was stabbed in its heart with a sharp instrument. The carcasses were put in cages, covered with poultry wire. The cages were placed at a distance of $20 \mathrm{~m}$ from each other.

\section{Site description}

The study area was located in an open field with a few medium-sized trees and bushes at Winangun in Manado, the capital city of North Sulawesi, Indonesia. According to the climate classification of Köppen-Geiger, Indonesia is identified as a tropical rainforest country (Af). ${ }^{21}$

\section{Procedures}

Observation of insects visiting the carcasses and measurement of ambient air temperatures and relative humidity with a thermo-hygrometer Meter were done twice daily (09.00 AM and 03.00 PM). Collected insects, adult and immature, were morphologically identified. Besides that, immature insects were reared in the Laboratorium of the Agriculture Faculty, University of Sam Ratulangi, Manado. Temperatures and humidities of the site area were obtained from Badan Meteorologi Klimatologi dan Geofisika (BMKG) Climatology Station, Kayuwatu, Manado during January 2012. The whole study was conducted during 15 days.

\section{RESULTS}

\section{Temperature}

During this study, ambient air temperatures at the site were $26.6-29^{0} \mathrm{C}$. According to the Climatology Station, Kayuwatu, temperatures at Winangun, Manado were $23.4-26.6^{\circ} \mathrm{C}$ and the humidities were 49-70\%. Temperatures in the laboratory were $28-29^{\circ} \mathrm{C}$ and the humidities were $62-66 \%$.

\section{Decomposition}

There were five observable stages of decomposition: fresh, bloated, active decay, post decay, and skeletonization. The duration of stages were the same on the second and the third pigs, but most of them (active, post decay, and skeletonization) were longer on the first pig. 


\section{Collected and reared Non-Calliphoridae- Necrophagous Diptera}

Collected adults of Non-CalliphoridaeNecrophagous Diptera were Sarcophagidae (flesh fly, Figure 1), Piophilidae (skipper fly, Figure 2), Ophyra (Hydrotea, dump fly, Figure 3), Phoridae (scuttle fly, Figure 4), Musca domestica (house fly, Figure 5), and Hermetia illucens (black soldier fly, Figure $6)$.

Immature insects found were the larvae of Ophyra (until day 15 at the study site) and pupae of Phoridae (during rearing). Adults of Musca domestica and Hermetia illucens were found during rearing, using the soil surrounding the carcasses.

\section{DISCUSSION}

Sarcophagidae species are spread world-wide, especially in tropical and temperate areas. ${ }^{3}$ Adult flies feed on sugar containing materials such as honey, plant sap, and honeydew. They are also found feeding on carrions and decaying plants. ${ }^{3,22}$ Larvae feed on decomposed organic matter, and most of them are necrophagous and saprophagous. ${ }^{3,5,22,23}$ Sarcophagidae species are attracted to carcasses in a variety of conditions: sunlit or shade, dry or wet, and indoor or outdoor. Larvaposition can occur in early and late stages. They usually come at the same time or not long after Calliphoridae species. ${ }^{3,5}$ According to Villet (2011), Calliphoridae and Sarcophagidae dominated the carcasses' ecosystem in Africa. ${ }^{24}$ According to Byrd and Castner (2010), Sarcophagidae species flew well, even in a bad weather, so they had the chance to come first to a corpse or carcass. ${ }^{3}$ In this study, adults of Sarcophagidae visited the carcasses on the first day post mortem and then during the whole study, but no larvae were found until the end of the study. It means that the colonization of Sarcophagidae did not occur in the carcasses.

Adult Piophilidae species are found on garbage, carrions, corpses, bones, skin and leather, and naturally dried high-protein materials. ${ }^{3,25}$ They are mostly found in the late active decay and early dry stages. ${ }^{3,5,26}$ Larvae and adult flies feed on carcassses and decomposed materials. ${ }^{3,22}$ In this study, adults were found in day 7 (post decay stage) but immature insects were not found during the whole study. It means that the colonization of Piophilidae did not occur in the carcasses.

Hermetia illucens was first reported in the United States and has spread to the other continents ${ }^{25}$ in tropical and temperate countries. ${ }^{3,27}$ Adults are not strong fliers, and are found around bushes and flowers, seeking honey. ${ }^{4,25}$ They are also found in garbage, manure, and decaying plants. $^{28}$ Larvae feed on decomposed materials of fruits, animals, and manure, ${ }^{3,4,25,27,29}$ human feces, and dung. ${ }^{4}$ Besides that, they are predators of other Diptera larvae. ${ }^{4}$ In tropical areas, $H$. illucens can be found all year. ${ }^{30}$ This species is not usually found in corpses and it colonizes in the later decomposition stages, 20-30 days post mortem. ${ }^{5,12,30}$ In this study, Hermetia illucens visited the carcasses at day 5 and 6 post mortem (active decay stage). Gunn (2009), Goff (2011), and Tomberlin et al (2005) reported that adult females did oviposition in the advanced /putrid decay. ${ }^{5,12,30}$ The second generation of Hermetia illucens was found during rearing (day 35-39), using the soil surrounding the carcasses. It means that the colonization of this species occured in the carcasses which was appropriate to their larvae' nature as being necrophagous and predatory to the other Diptera larvae. ${ }^{3,4,25,27,29}$

Adults of Ophyra are attracted to carrion and excrement. Although larvae develop primarily in feces, second and third instars are predacious, and they attack larvae of Musca domestica and other Muscidae species if they are at the same place. ${ }^{3,25,31}$ In this study, adults visited the carcasses from day 1 until day 8 , and larvae were found from day 6 until day 14 (fresh stage until skeletonization). It means that the colonization of this species occured in the carcasses. 


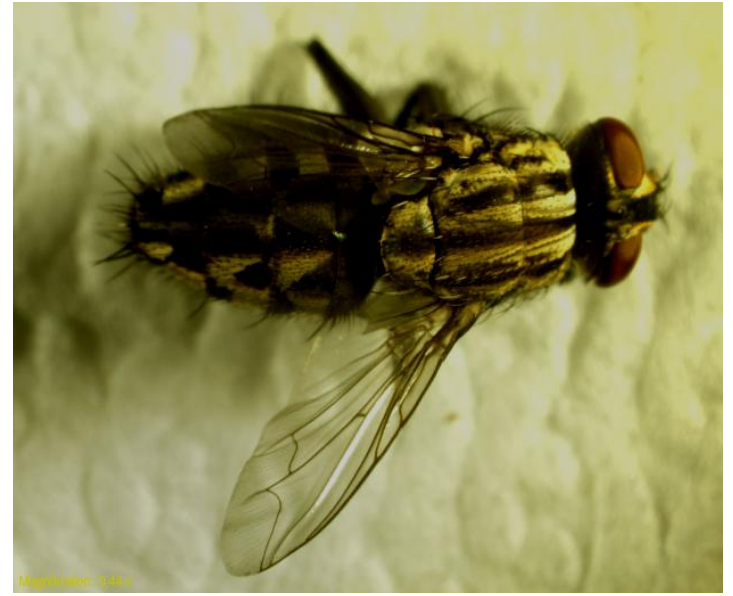

Figure 1. Sarcophagidae: dorsal view.

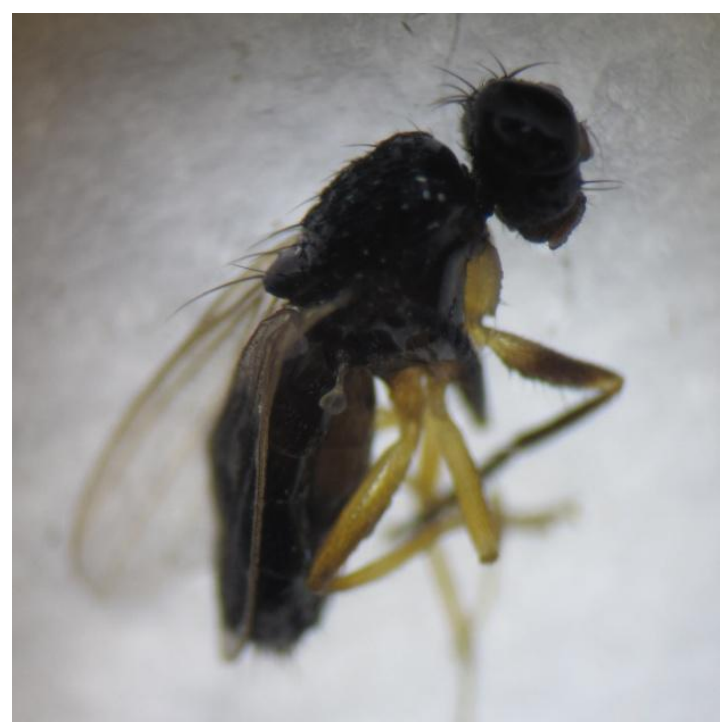

Figure 2. Piophilildae: lateral view.

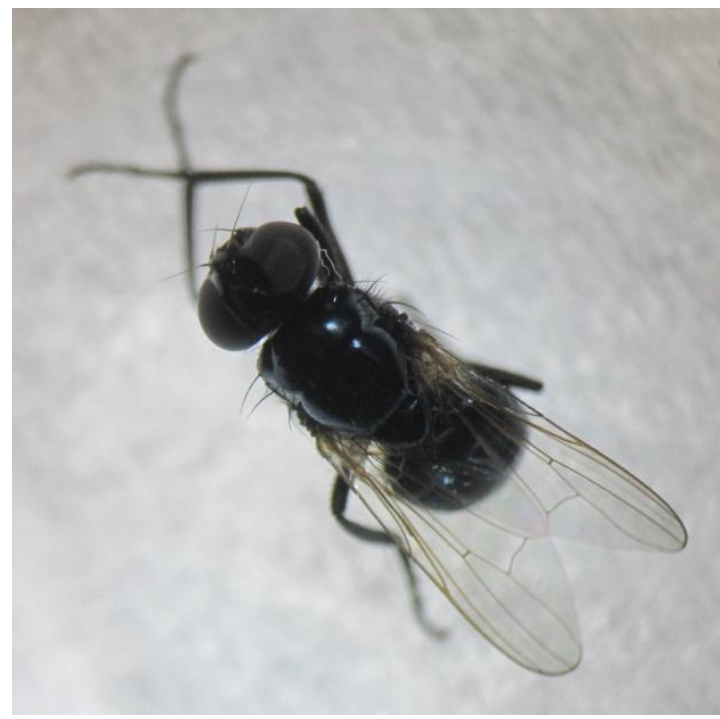

Figure 3. Ophyra: dorsal view.

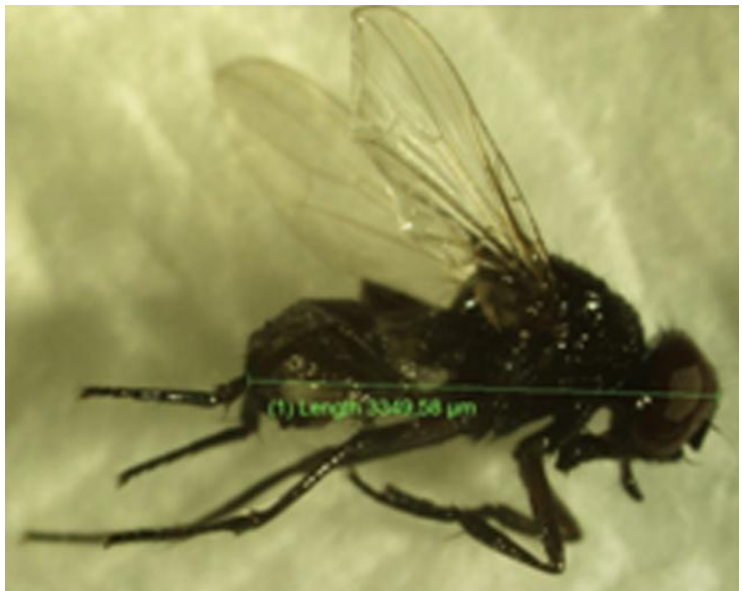

Figure 4. Phoridae: lateral view.

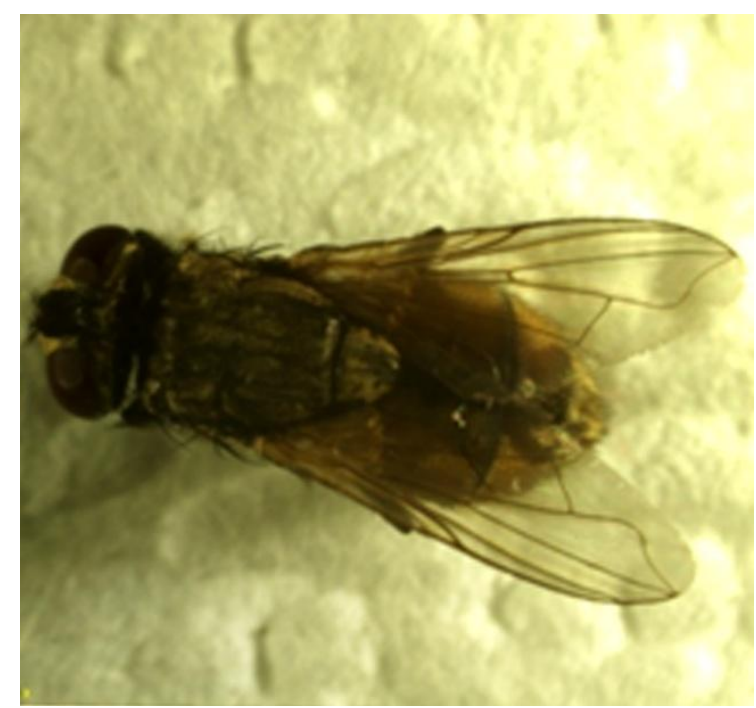

Figure 5. Musca domestica: dorsal view.

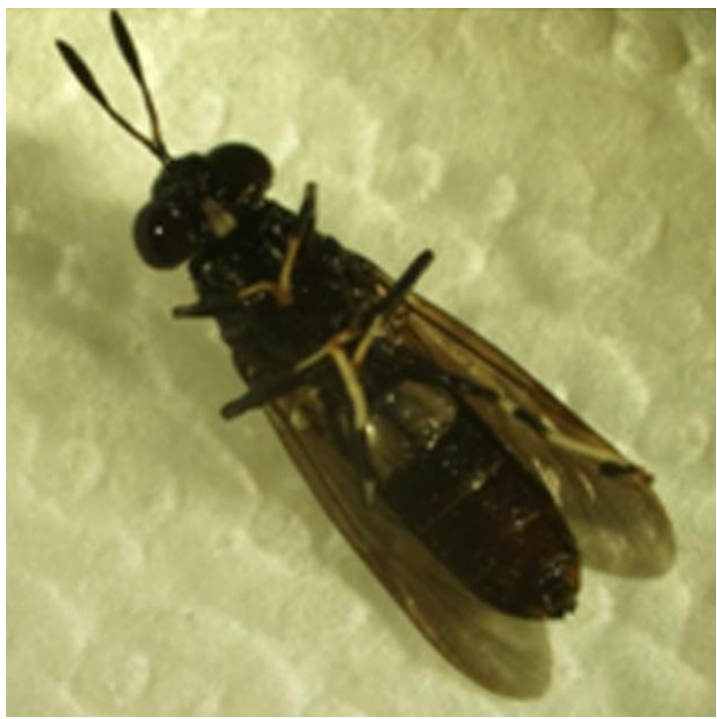

Figure 6. Hermetia illucens: ventral view. 
Musca domestica is the most frequently found species of Muscidae..$^{3,5,25}$ They are attracted to carrion due to feces or exposed gut contents, body excudate, sweet food, meat, and decomposed plants. ${ }^{3,5,25,26}$ Larvae are saprophagous and they feed on feces, decomposed plants, and tissues of corpses/carcasses. ${ }^{3,5}$ Besides that, they are predators of eggs and larvae of other Diptera $^{3}$ Adults of Musca domestica mostly visit corpses shortly after Calliphoridae and Sarcophagidae in active and post decay stages. They rarely visit fresh corpses, unless there is feces or exposed gut contents. $^{3,5,25}$ In this study, Musca domestica visited the carrion from day 2 (bloated stage) until day 5 (active decay stage), earlier than the stages suggested by Byrd and Castner (2010), Gunn (2009), and Smith (1986). ${ }^{3,5,25}$ The early arrivals of adult insects were beneficial to larvae development since they were predators of eggs and larvae of other Diptera, in this case Chrysomya species. Adult flies were found during larva rearing in the laboratory after seven days. This species needs a relatively high temperature to complete its life cycle in an optimum condition, which are 6-8 days. ${ }^{5}$

The Phoridae family is spread worldwide, especially in tropical countries. ${ }^{32}$ Adults of Phoridae are found on decaying plants and organic matter. ${ }^{3,22,25,32}$ Larvae feed on a variety of materials, and as detritivores they are found in decomposed plants, animals, corpses (on the ground or burried), fungi, as internal parasites in a variety of insects, commensal in ant or termite nests, ${ }^{3,5,22,32}$ parasitoid, and as predators of other larvae. ${ }^{3,5,25,32}$ According to Gunn (2009), Phoridae species visited carcasses in later stages when the remains began to dry. ${ }^{5}$ In this study, adult Phoridae species were found in day 5 (active decay stage), which favored these flies since their larvae were predators of other Diptera larvae. Pupae and adult flies were found during rearing using soil surrounding the carcasses. It means that Phoridae species had colonized successfully on the car- casses.

\section{CONCLUSION}

There were five observable decomposition stages (fresh, bloated, active decay, post decay, and skeletonization) of domestic pig carcasses in Manado, Indonesia. Non-Calliphoridae-Adult-Necrophagous Diptera visiting the carcasses were Ophyra, Piophilidae, Phoridae, Sarcophagidae, Musca domestica, and Hermetia illucens. Ophyra, Phoridae, Musca domestica, and Hermetia illucens colonized succesfully in the carcasses.

\section{Suggestion}

It is suggested that database and successions of Non-Calliphoridae-Necrophagous Diptera and other forensic insects can be applied optimumly in the medicolegal investigation.

\section{Acknowledgements}

We would like to thank to Ir. James Kaligis MSi from the Plant Pests and Diseases Laboratory, Faculty of Agriculture, University of Sam Ratulangi, Manado, who assisted in providing digital recording data equipment; and to reviewers at the University of Sam Ratulangi Manado who provided useful critiques of the manuscript.

\section{REFERENCES}

1. Amendt J, Krettek R, and Zehner R. Forensic entomology. Naturwissenscahften. 2004; 91:51-60.

2. Benecke M. Forensic Entomology: Arthropods and corpses. Forensic Pathology Reviews. 2004;2:1-16.

3. Byrd JH, Castner JL. Insects of forensic importance. In: Byrd JH, Castner JL, editors. Forensic Entomology: The utility of arthropods in legal investigations (Second Edition). Boca Raton: CRC Press, 2010: p.39-122.

4. Gillott C. Entomology (Third Edition). Dordrecht: Springer, 2005. 
5. Gunn A. Essential Forensic Biology (Second Edition). Chichester: WileyBlackwell, 2009.

6. Sembel DT. Entomologi Kedokteran. Yogyakarta: Penerbit Andi Yogyakarta, 2009.

7. Benecke M. A brief history of forensic entomology. Forensic Sci. Int. 2001;120:2-14.

8. Amendt J, Campobasso CP, Gaudry E, Reiter C, LeBlanc HN, Hall MJR. Best practice in forensic entomologyStandards and guidelines. Int $\mathrm{J}$ Legal Med. 2006. DOI 10.1007/s00414-0060086-x.

9. Greenberg B, Kunich JC. Entomology and the law Flies as forensic indicators. Cambridge: Cambridge University Press, 2002.

10. DiMaio VJ, DiMaio D. Forensic Pathology (Second Edition). Boca Raton: CRC Press, 2001.

11. Campobasso CP, Di Vella G, Introna F. Factors affecting decomposition and Diptera colonization. Forensic Sci.Int. 2001;120:18-27.

12. Goff ML. Forensic entomology. In: A. Mozayani, C. Noziglia, editors. The Forensic Laboratory Handbook Procedures and Practice (Second Edition). New York: Humana Press, 2011; p.448-54.

13. Huijbregts J, Krikken J. Forensische entomologie. In: Broeders APA, Muller ER, editors. Forensische Wetenschap, Studies over forensische kennis en organisatie. Deventer: Kluwer, 2008; p. 440.

14. Adair TW, Kondratieff MS, Kondratieff BC. Three species of insect collected from an adult human corpse above $3300 \mathrm{~m}$ in elevation: A review of a case from Colorado. J. Forensic Sci. 2006;51(5):1164-5.

15. Sharanowski BJ, Walker EG, Anderson GS. Insect succession and decomposition patterns on shaded and sunlit carrion in Saskatchewan in three different seasons. Forensic Sci. Int. 2008;179:219-39.
16. Williams KA, Villet MH. A history of Southern African research relevant to forensic entomology. South African Journal of Science. 2006;102:59-63.

17. Barbosa RR, de Mello-Patiu CA, de Mello RP, de Carvalho Queiroz MM. New records of Calyptrate Dipterans (Fanniidae, Muscidae and Sarcophagidae) associated with the decomposition of domestic pigs in Brazil. Mem Inst Oswaldo Cruz. 2009;104(6):923-26.

18. Catts EP. Problems in estimating the postmortem interval in death investigations. J. Agric. Entomol. 1992;9(4):245-55.

19. Singh M, Kulshrestha P, Satpathy DK. Synchronous use of maggots and diatoms in decomposed bodies. JIAFM. 2004;26(3):121-3.

20. Tuzun A, Dabiri F, Yuksel S. Preliminary study and identification of insects' species of forensic importance in Urmia, Iran. African Journal of Biotechnology. 2010;9(24):3649-58.

21. Peel MC, Finlayson BL, McMahon TA. World map of Köppen-Geiger climate classification [homepage on the Internet]. Nodate [cited 2012 January 30]. Available from URL: http://en.wikipedia.org/wiki/

File:Koppen_World_Map.png. Last updated on 18-07-2010.

22. Triplehorn CA, Johnson NF. Borror and deLong's Introduction to the Study of Insects (Seventh Edition). Belmont: Thomson Brooks/Cole, 2005.

23. Al-Misned FAM. Effects of larval population density on the life-cycle of flesh fly, Wohlfahrtia nuba (Wiedemann) (Diptera: Sarcophagidae). Saudi. J. Biol. Sci. 2002;9(2):140-147.

24. Villet MH. African carrion ecosystems and their insect communities in relation to forensic entomology. Pest Technology (Global Science Book). 2011;5(1):1-15.

25. Smith KGV. A Manual of Forensic Entomology. London: Trustees of the British Museum (Natural History), 1986.

26. Gennard DE. Forensic Entomology: An Introduction. London: John Wiley \& Sons Ltd., 2007.

27. Tomberlin JK, Shepard DC. Lekking behavior of the Black Soldier Fly 
36 Jurnal Biomedik, Volume 4, Nomor 1, Maret 2012, hlm. 30-36

(Diptera: Stratiomydae). Florida Entomologist. 2001;84(4):729-30.

28. Turchetto $M$, Lafisca $S$, Constantini G. Postmortem Interval (PMI) Determined by study Sarcophagous biocenoses: Three cases from the Province of Venice (Italy). Forensic Sci. Int. 2001;120:28-31.

29. Newton DW, Shepard S, Burtle G, Dove R. Using the black soldier fly, Hermetia illucens, as a value-added tool for the management of swine manure. A report for director of the Animal and Poultry Waste Management Center. Raleigh: North Carolina State University, 2005.
30. Tomberlin JK, Sheppard DC, Joice JA. 2005. Black soldier fly (Diptera: Stratiomyidae) colonization of pig carrion in South Georgia. J Forensic Sci. 2005;50(1):1-2.

31. Vibe-Petersen S. Development, survival and fecundity of the urine fly Scatella (Teichomyza) fusca and predation by the black dump fly, Hydrotaea aenescens. Entomologia Experimentalis et Applicata. 1998;87: 157-69.

32. Sembel DT. Pengendalian Hayati Hamahama Serangga Tropis \& Gulma. Yogyakarta: Penerbit Andi Yogyakarta, 2010. 